\title{
ИСТОКИ ИННОВАЦИОННЫХ КЛАСТЕРОВ: ВЛИЯНИЕ СРЕДНЕВЕКОВЫХ ГИЛЬДИЙ
}

\author{
(C) 2020 Костин Святослав Владимирович \\ аспирант факультета государственного управления \\ МГУ имени М.В. Ломоносова, Россия, Москва \\ E-mail: KostinSV@spa.msu.ru
}

В статье рассматривается вопрос происхождения кластеров в целом и инновационных кластеров в частности. Показано, что корни происхождения кластеров следует проводить не с XIX века, когда начались первые исследования пространственной связанности экономики, а со Средних веков, когда появились гильдии как главные институты организации экономической жизни общества. Как следует из приведенных в тексте примеров, гильдии исполняли прогрессивные социальноэкономические функции, а также показали ценность концентрации человеческого капитала. Делается вывод, что многие характеристики и практики гильдий находят отражение и в инновационных кластерах нашего времени.

Ключевые слова: инновационный кластер, гильдия, инновационный процесс, «услужение», конкуренция

Пандемия коронавируса и связанные с нею ограничения существенно изменили функционирование экономики. Многие и многие процессы были вынуждены переместиться в цифровой формат, исполняться сотрудниками на удаленном доступе и выводить результаты в режиме онлайн или остановиться на время пандемии. Сложно сказать, были ли способы избежать пандемии и введенных в связи с ней ограничений, но развитие современных средств коммуникации, информационных систем определенно ослабило их влияние на хозяйственную деятельность.

В связи с этим вновь возобновляются споры вокруг географической концентрации инновационных предприятий - точнее, ее необходимости. Совместная исследовательская работа, прототипирование в 3D, поиск и получение финансирования в виде инвестиций или банковских кредитов, продвижение продукта, продажа - все эти процессы уже имеют обслуживающие их сервисы в Интернете. Даже производство может быть удаленным - в некоторых отраслях современные роботизированные станки и 3D-принтеры способны воспринимать предложенные разработчиками модели напрямую.

Однако же, на самом деле география все еще имеет место в инновационном дискурсе. Во-первых, рабочая сила и в т.ч. человеческий капитал все еще достаточно сильно привяза- ны к конкретным легальным, политическим, социально-экономическим условиям, чтобы быть конвертированными для участия на других рынках без заметных потерь. Во-вторых, эффекты очной коммуникации в инновационном процессе все еще являются куда более сильными и долгосрочными, нежели коммуникации онлайн. Так что и в России, и в других странах принимаемые планы восстановления экономики содержат меры стратегического характера по поддержке и развитию инновационных кластеров - так, в России планируется дальнейшее совершенствование механизма реновации промышленных зон для создания на их территории современной научно-технологической инфраструктуры, а также создание инновационных научно-технологических центров (ИНТЦ), вместе с научными образовательными центрами (НОЦ) и центрами компетенций Национальной технологической инициативы (НТИ) служащими достижению целей национальных проектов [3].

Вместе с тем, нынешний кризис явился отличным поводом для переосмысления концепции инновационных кластеров. В долгосрочном периоде действительно многие функции, обязывавшие ранее сотрудников находиться на рабочих местах, можно будет осуществлять удаленно, и тем снижается роль сдерживающих факторов в существовании инновационных кластеров. Однако случится ли то же самое с ролью моти- 
вирующих факторов - вопрос, который требует отдельного рассмотрения.

Например, еще в 2000-е гг. доминировала теория, делавшая упор на либерально-культурный детерминизм, наиболее видным представителем которой был Ричард Флорида. Считалось, что поощрение доминирования либерального дискурса и есть ключ к восстановлению или усилению экономической активности в данной местности - на этом строилась концепция «джентрификации», перестройки старых районов с целью сделать их привлекательными для артистов и молодых предпринимателей, присутствие которых, как считалось, коррелирует между собой. Однако после мирового экономического кризиса 2008-2010 гг. в США начался отток как раз инновационных предпринимателей из традиционно считающейся вотчиной демократов Калифорнии в консервативный республиканский Техас.

Это не столь удивительно, как может показаться. Еще в 1976 г. Honda решила открыть первый завод по производству своей автотехники в США именно в Калифорнии - первом по объему продаж своих машин и численности населения штате, уже тогда славившемся высокотехнологичными разработками в области вычислительной техники и поддержкой контркультурных течений. Однако, когда глава Honda Motor America Шиге Йошида на переговорах с губернатором Калифорнии Джерри Брауном решил спросить его, какие причины он бы назвал для открытия их завода, Браун, носивший прозвище «Лунатик» (Moonbeam), ответил: «Хиппи, синие джинсы и то, что любая мода начинается в Калифорнии» [7, 91]. В результате завод Honda был построен в Огайо, равно как и все последующие автопроизводители обходили Калифорнию стороной.

В связи с этим следует рассмотреть инновационные кластеры более глубоко, чем мы привыкли думать. Привычно считать инновационные кластеры изобретением второй половины XX века, продуктом пятого техникоэкономического уклада - однако, как известно, ex nihilo nihil fit («из ничего ничего и возникнет). Известно, что кластерную теорию в современном ее виде впервые сформулировал Альфред Маршалл, показав, что при определенных условиях совокупность малых предприятий может успешно конкурировать с фабриками, что и про- исходило в современных ему «промышленных районах» крупных городов Англии. Побуждали предпринимателей и работников к сближению друг с другом насыщенный рынок труда, где каждый мог сравнительно легко найти работу или работника, разделение труда между фирмами и переток знаний между работниками [9. 289-290]. Легко заметить, что в каждом случае мы имеем дело с положительной обратной связью или возрастающей отдачей от каждого нового участника.

Однако странным представляется, что при анализе локализации экономической деятельности до промышленного переворота А. Маршалл приводит иные факторы: природные условия и покровительство двора, создававшее спрос на качественные товары и квалифицированных работников. При этом знания во многом фиксируются как величина константная: английских работников обучили приглашенные двором иммигранты, квалификация которых была определена также природными условиями и знаниями предков вплоть ранних цивилизаций Древнего мира. Хотя в тексте упоминается, что «почти всякое важное знание имеет глубокие корни, простирающиеся в далекое прошлое», относить это к инновационным кластерам было не принято. Вопрос об их происхождении во многих работах обходился стороной*.

На взгляд автора, наиболее актуальным представляется рассмотреть период, когда впервые претворилась в жизнь концепция локальных профессиональных объединений лично свободных ремесленников и иных людей труда - Средние века. Именно в это время в Европе возникают институты, являющиеся незаслуженно забытыми предками кластеров и способные пролить свет на некоторые их современные особенности - гильдии.

Прежде всего, гильдии совершенно определенно не являлись консервативным институтом по природе. Популярное заблуждение об отрицательной роли гильдий в экономическом развитии возникло уже в эпоху Просвещения, когда гильдии во многом действительно противодействовали внедрению новых изобретений в ведомые ими отрасли. Однако распространять этот период в истории на весь институт - значит поддаваться логической ошибке post hoc ergo propter hoc («после» значит «вследствие»).

\footnotetext{
* Единственная работа, затрагивающая данную тему: Akoorie, M.E.M. (2011). A challenge to Marshallian orthodoxy on industrial clustering. Journal of Management History, 17(4), 451-470
} 
Оставляя пока причины деградации института, заметим, что изначально гильдии были экономическим институтом, существенно обеспечившим технико-экономический прогресс в городах Средневековья.

Во-первых, разберем вопрос обучения и трансфера полезных технических знаний. Известно, что до появления фабрик товарное производство осуществлялось во многом домохозяйствами, в которых передача знаний между поколениями, от старшего к младшему происходит естественным образом в процессе работы. Однако на практике в городах на протяжении всей т.н. «мальтузианской эры» наблюдался устойчивый отрицательный естественный прирост населения. Крайнее несовершенство систем общественного хозяйства приводило к весьма высокой смертности, компенсируемой лишь за счет миграции сельского населения. Как пишет Грегори Кларк о Лондоне, «почти у 60\% лондонских завещателей не оставалось сыновей», в то время как на территории остальной Англии бездетными умирали всего треть завещателей [8, 231-232]. Следовательно, говорить об устойчивости семейного трансфера знаний не приходится - он мог играть важную, но не определяющую роль.

К сожалению, университеты также не могут претендовать на лидирующую роль в данной области. Действительно, университеты являлись центрами сосредоточения интеллектуальных ресурсов и человеческого капитала, пользовались широкими правами самоуправления (вплоть до выбора студентами профессоров). Однако в их методе обучения отсутствовала ключевая составляющая инновационного процесса - конкурентность. Целью дискуссий было не достижение истины, а оттачивание искусства риторики, потому каждый участник должен был доказывать не одну, но обе точки зрения на предмет спора, и поощрялось умение аргументации в целом независимо от излагаемой гипотезы [5, 92]. Кроме того, совершаемые профессорами или их подопечными открытия спокойно заимствовались друг другом без указания автора. Так что, ни в одном из действительных технологических прорывов Средневековья, будь то изобретение водяной мельницы, маятниковых часов, блока и лебедки, университеты и ученые замешаны не были [4]. Подлинно значимую роль в сохранении и приумножении знаний играли как раз гильдии, поощрявшие авторство через систему именных клейм мастеров и создавшие систему «услужения» (service) для массового отбора и обучения мастерству.

Данная система заслуживает более внимательного рассмотрения. Известно, что мастерачлены гильдий подчинялись некоторым правилам и ограничениям в отношении набора учеников и содержания их обучения, однако данные правила принимались исключительно общим собранием мастеров и были обычно не столь обременительны для них. Подростки, а нередко и дети, шли в учение к мастеру, где сперва в качестве учеников выполняли самую тяжелую и простую черновую работу, потом уже в качестве подмастерьев выполняли более ответственную деятельность. Выполнение «шедевра», доказывавшего их профессионализм, и одобрение коллегией мастеров позволяли подмастерью обрести статус мастера и с этой поры стать самостоятельным, работать на себя, жениться или выйти замуж, приобрести дом или лавку. «Услужение» воспринималось как необходимый процесс профессиональной и социальной адаптации, в котором молодые люди приобретают необходимые их группе манеры и дисциплину - но вознаграждение также являлось частью процесса. Предполагалось, что подмастерья одновременно обретают практические знания для управления своим хозяйством (семьей и мастерской, понятия до промышленной революции почти не различимые) и капитал для его строительства [2]. Из этого следует, что «услужение» как практика наемного труда воспринималось как необходимый этап взросления человека, после которого он начинает работать на себя.

Во многом описанный механизм схож с механизмом циркуляции сообщества в инновационном кластере. Так же, как и в гильдиях, действует практика стажировок (но уже зачастую неоплачиваемых) с целью обучения персонала. Развитая инфраструктура побуждает людей воспринимать наемный труд в стартапах как необходимый этап на пути создания собственного. Так, высокие зарплаты в инновационных предприятиях и сравнительная доступность кредитования, в т.ч. «посевного», предоставляют работникам «состояние» для организации собственного дела, в то время как работа в уже размещенных на территории кластера предприятиях дает необходимые знания, а также связи для организации команды стартапа.

Во-вторых, разберем вопрос производства 
и использования полезных знаний. Даже в условиях дороговизны письменных источников гильдии разных городов и феодальных владений активно взаимодействовали друг с другом, через поездки мастеров и подмастерьев поддерживая единые стандарты работы (хотя Ричард Сеннет утверждает, что это могло происходить в т.ч. за счет унификации и статичности передаваемых навыков [11, 70]). В отличие от университетов, поощрялась конкуренция между мастерами по качеству товаров, подтверждаемому экспертизой на основе четко установленных критериев. Более того, некоторые гильдии периодически вводили единоразовые сборы со своих членов для выкупа и передачи в общее пользование новых производственных техник у их изобретателей [1]. В отличие от «давальческой» системы надомного производства, гильдии давали своим членам наблюдать работу друг друга и сравнивать результаты, что также давало стимулы к сглаживанию различий в эффективности и росту общей производительности труда [10, 172].

Бесспорно, современные инновационные кластеры отличаются от гильдий новыми методами организации инновационного процесса. Однако именно гильдии дают нам впервые пример системной организации «благотворных кругов» накопления и использования знаний в производстве. Впервые были утверждены концепции авторства, профессиональной открытой конкуренции на основе объективных критериев и экспертизы, бенчмаркинга,

В-третьих, разберем вопрос управления. Как уже было указано ранее, порядок обучения работников утверждался на общем собрании членов гильдии, однако так же утверждались и остальные законы и ограничения. Впервые гильдии как профессиональные объединения, равно как и родственный им институт братств (fraternitas), появляются в Европе в X-XI вв. как conjuratio - объединение на основе взаимной клятвы объединенных профессией работников. В отличие от васссальных клятв, гильдейская клятва утверждала отношения равных - обязательства (прежде всего, по взаимной защите жизни, прав и имущества) распространялись на всех без исключения, к приему в гильдии допускались женщины [6]. Почти полностью отсутствовал профессиональный бюрократический аппарат - необходимые функции возлагались на членов гильдии на определенный срок.

Конечно, инновационные кластеры не могут быть настолько свободны от бюрократии просто в силу сложности современных процессов производства и управления. Но при этом они все равно выигрывают у корпораций и государственных предприятий в привлекательности для желающих рыночного успеха изобретателей - почти все административные функции берет на себя управляющая организация, предоставляя при этом полную профессиональную свободу. Конечно, в отличие от гильдий, кластеры не заботятся о социальной и духовной сфере жизни предприятий, однако зато предлагают гораздо больше мер, задуманных для ускорения их экономического роста, но исполняющих и функцию формирования профессионального сообщества - форумы, профессиональные школы, тренинги и т.д.

Подводя итог, можно сказать, что гильдии были полезным экономическим институтом, сумевшим аккумулировать, сохранить и развить ремесленные знания в средневековой Европе. Не отрицая роль монастырей и университетов, именно гильдии обеспечивали отмеченные еще А.Маршаллом эффекты: высоко насыщенный рынок труда, разделение труда и «эффект перелива» знаний между участниками. Кроме того, именно в гильдиях существовала та специфическая культура профессионального братства, которая сейчас считается одним из ключевых и наиболее трудно эмулируемых преимуществ Кремниевой долины в Сан-Франциско, «Шоссе 128» в Бостоне и некоторых других инновационных кластеров.

Безусловно, стоит выделить и реперные точки, в которых гильдии как институт сделали неверный выбор и деградировали. Получение гильдиями политической власти очень часто приводило к переходу на рентоориентированное поведение, подавление независимых изобретений и выделение группы профессиональных «политиков-управленцев», что влекло прекращение внутренней конкуренции. Перенос производства в сельскую местность и переход на «давальческую» систему производства товаров домохозяйствами, который можно назвать забытой «нулевой» промышленной революцией, отнял во многом у гильдий в пользу данных хозяйств функцию накопления и передачи человеческого капитала в привычном виде обучения на производстве [10, 173], но гильдии не воспользовались шансом создать новую, более научно организованную систему обучения. 
Замкнутость на избранной профессиональной сфере не позволила гильдиям продолжить углубление разделения труда и, что более важно, осуществлять междисциплинарные связи, из которых и рождается большинство инноваций. Все эти и некоторые иные проблемы, пусть и в новых формах (надомное производство касается уже в первую очередь объектов интеллектуальной собственности), актуальны и в наше время. Именно поэтому опыт средневековых гильдий, долго пребывавший «слепым пятном», достоин изучения при проектировании новых и управлении существующими инновационными кластерами.

\section{Библиографический список}

1. Epstein, S.R. (1998). Craft Guilds, Apprenticeship, and Technological Change in Preindustrial Europe Journal of Economics History 58 (3): 684-713

2. Graeber, D. (1997). Manners, Deference, and Private Property in Early Modern Europe. Comparative Studies in Society and History, 39(4), 694-728

3. https://www.economy.gov.ru/material/departments/d01/razvitie_sistemy_gosudarstvennoy_podderzhki_ innovaciy_v_subektah/intc/ (20.06.2020)

4. White L. T. The Medieval Roots of Modern Technology and Science // Medieval Religion and Technology: Collected Essays. Berkeley: University of California Press, 1978-75-91

5. Вуттон, Дэвид. Изобретение науки. Новая история научной революции. М.: КоЛибри, 2018. -656 с.

6. Герхард Эксле, Отто. Действительность и знание: очерки социальной истории Средневековья. М.: Новое литературное обозрение, 2007.-360 с.

7. Инграссия, Пол. Падение титанов. Сага о «Форде», «Крайслере», «Дженерал Моторс» и упущенных возможностях. М.: Карьера Пресс. 2012.- 384 с.

8. Кларк, Грегори. Прощай, нищета! Краткая экономическая история мира. М.: Издательство Института Гайдаpa, 2013. $-544 \mathrm{c}$.

9. Маршалл, Альфред. Принципы экономической науки: в 3 т. Т.1. М.: Прогресс, 1993.- 414 с.

10. Мокир, Джоэл. Дары Афины. Исторические истоки экономики знаний. М.: Издательство Института Гайдара, 2012.- 408 c.

11. Сеннет, Ричард. Мастер. М.: Strelka Press, 2018.- 328 c. 